\title{
Research on the Strategic Development of the Reform and Transformation of Independent College to Application-Oriented College
}

\author{
-Deepen the reform of the system and mechanism of application-oriented college
}

\author{
Wan Zhiping \\ Information Science Department \\ Xinhua College of Sun Yat-Sen University \\ Guangzhou, China \\ wzp888_0@126.com
}

Li Jing

Department of Management

Xinhua College of Sun Yat-Sen University

Guangzhou, China

87964930@qq.com

\author{
Liu Shuang \\ Academic Affairs Department \\ Xinhua College of Sun Yat-Sen University \\ Guangzhou, China \\ 619900469@qq.com \\ Wang Feng \\ Information Science Department \\ Xinhua College of Sun Yat-Sen University \\ Guangzhou, China \\ 78133090@qq.com
}

\begin{abstract}
Independent colleges as local colleges, after more than 10 years of development, from initial infrastructure development to the current internal development, based on Parent College rapid promotion, has playing a great role in the whole undergraduate education. From the collaborative innovation development to the current transformation, independent colleges are in full swing for the education reform. Through the strategic objectives of transformation, independent colleges are conducive to the structure of higher education, cultivate more application-technical talents in the region, also make the greater contribution to local economic development, and vigorously promote the development of double-qualified teachers and reasonable subjects' arrangement. Under the change of talent cultivation, we should complete the top-level design and the innovation institutional mechanism reform in colleges.
\end{abstract}

Keywords-Independent College; application-technical talents; double-qualified teachers; reasonable subjects' arrangement; reform of innovation institutional mechanism

\section{INTRODUCTION}

The development of independent colleges has experienced several stages of education reform, from collaborative innovation to application, the country and the provinces and municipalities have introduced the corresponding documents, policies, and regulations. "National Medium-Long-Term Educational Reform and Development Plan (2010-2020)”, published on July 29, 2010, points out that knowledge innovation, technological innovation, national defense science and technology innovation, and to promote regional innovation, universities, research institutes, enterprises of science and technology education resource sharing, promote the innovation organization mode of colleges and universities, foster

Education research project of Guangdong Education Research Institute, 2014 (GDJY-2014-C-b026). interdisciplinary, cross-disciplinary research and teaching team, enhance the level of personnel training, and social economy development[1]. "Opinions of the Ministry of Education on improving the quality of higher education (higher [2012] No.4)”, released on March 16, 2012, pointed out that the increment of the scale of higher education is mainly used for developing higher vocational education, continuing education, professional degree graduate education and the expansion of private education and cooperation in running schools. The university should optimize the structure, adjust the discipline, type, level, and regional layout structure, adapt to the national and regional economic and social development needs, to focus on the reform of institutional mechanisms, to encourage local and University bold exploration experiment. To strengthen the construction of local colleges and universities, based on the principles of to help and support, to play the role of resource allocation, to support the development of the characteristic of the high level of local universities. Using innovation, education teaching methods, propose advocating heuristic, exploration, discussion, participatory teaching. Promote scientific research and teaching interaction, timely scientific research into teaching content, key laboratories, research base open to students. Support for undergraduates to participate in scientific research activities, early into the topic, the laboratory and the team. Reform the examination method, pay attention to the learning process and students' ability evaluation. Explore the establishment of open, integrated and efficient new model, for example, school collaboration, school enterprise (industry) coordination, school district (regional) collaboration, international cooperation etc.[2]. In April 2014, 178 colleges jointly issued the "Zhumadian consensus" in the first "International forum on the development of education and education", which fully open the transform of local universities[3]. "The State Council on accelerating the 
development of modern occupation-education decision”, released on June 24, 2014, pointed out that, taken the ways of promoting, demonstration and guidance of the pilot, to guide a number of ordinary undergraduate colleges transform into applied technical colleges, focusing on the undergraduate vocational education. When the independent colleges are set up as independent institutions of higher learning, they are encouraged to position itself as applied technical colleges. Establish the classification system of colleges, implement classification management, and accelerate the establishment of classification settings, evaluation, guidance, funding system. Enrollment, investment and other policy measures towards to the applied technical colleges[4]. Ministry of education, the national development reform commission, the Ministry of Finance on the "Directive opinion of the transformation of local colleges into applied technical colleges” ([2015] No.7), October 23, 2015, pointed out that adhere to the top-level design, comprehensive reform, demand-oriented, service areas, the pilot first, demonstration lead, and the provincial coordination[5]. In June 2016, the Education Department of Guangdong Province issued "The implementation opinions of guiding general undergraduate colleges transform into the applied technical colleges", opinions pointed out that the school idea to serve the regional economy and social development, to the integration of production and education, school-enterprise cooperation, to the application of talents, to enhance students' innovation and entrepreneurship. Deepen the comprehensive reform of the management system, improve the internal governance structure, establish and improve the management mechanism in line with the characteristics of the application-oriented universities, revising the talent training plan, and deepen the reform of the training mode of applied talents. Based on regional development, promote the scientific research innovation of applied research orientation.

\section{REFORM AND OBJECTIVES OF THE STRATEGIC DEVELOPMENT} OF INDEPENDENT COLLEGE TRANSFORMATION OF APPLICATION TECHNOLOGY

Local undergraduate colleges and independent colleges are the main components of regional undergraduate education, but also the main force of the regional economy, transport a large number of high-quality compound talents for the local, especially when the local industrial is upgrading and high-end talent is demand. Colleges also have a clear positioning and development goals, constantly explore and try in the tide of education reform, take a variety of advanced educational concepts to improve the quality and level of running schools. In the trend of the reform of application-oriented undergraduate transformation, the position of colleges has a huge different, is also divided into many kinds and there are many different views. Although the purpose of education is to cultivate applied talents, there are also great differences in the teaching position and the development of the strategic level of the school, in the end, should be based on teaching or research, the focus of discussion is placed in the school's position. Some think that local colleges in the middle distribution level are because of their specificity, not as well as research universities, and higher than the vocational schools level, then it should be clear that the development thought is based on teaching or academic oriented, there are a lot of differences on this issue, even if the teaching and learning mixed school are also arguing with who is the most important, or both, and is divided into these three types in the development of the positioning. At present, the development of higher education in China has changed from the elite to the public and then to the universal. In the process of transformation, combined with the emerging educational technology, continue to deepen reform. After all, no matter what kind of mood, its strategic goal is to train the high-end talent to meet the needs of the society and the market. For local colleges and independent colleges, it is necessary to cultivate high-end talents of applied technology skill to adapt to the regional economic development and industrial structure adjustment to make up for this level of the talent gap, which can link up higher vocational education. Independent colleges as local colleges, its positioning is application-oriented colleges, to cultivate applied talents. The development strategy and layout should be set to industry oriented disciplines, train with a certain level of the application technical skills type composite high-end talent, and be able to become the senior professional in the industry. At the same time, taking into account the subject characteristics, which put forward the guidance of the transition. According to their own situation of all professional transformation or partial transformation, the overall goal of the transition is based on the actual situation of the school and the local industry layout and policy factors, set up its own special transformation system in the course of subjects' transformation and development, and eventually forming a special subject with regional advantages. The above mentioned three types, whatever based on teaching or academic-oriented, or to teaching-academic mixed type, in what way as the focus of the fight. It is based on the teachers' subjective cognition, unilaterally emphasized on what kind of specific guidance. The teaching service itself is the application type, technical skills are also the technical application type, and the academic type in improving the overall academic level has a great role in promoting. If we attach importance to the academic and ignore the application, resulting led to the application of the deviation of teaching, these are the wrong subjective understanding, the development and upgrading of the industry needs of high-end composite talent, technology, and theory are equally important. Different characteristics of the local university and the development of the foundation are not the same, and then they need to combine their actual situation to play a dominant discipline, with some disciplines to promote all disciplines. Give priority to the development of the characteristics of subject teaching and academic research, according to the development plan to formulate the strategic orientation of different stages at different levels, meanwhile, improve teaching quality and academic level, with the development of the school stage, the formation of professional characteristics of the industry. Gradually carry out partial transformation and overall transformation, through the level of development continues to promote the development of the work, the formation of top-level design, top-down transformation reform. The strategic approach should be combined with the characteristics of the school itself, in teaching and academic development in the formation of a balanced and complementary situation, promoting academic development from the teaching service type in the effort to improve the teaching quality, to academic-oriented, combined with the 
characteristics of the industry to carry out technical and practical teaching, to serve the local economy as the guide, to promote the combination of theory and practice. Academic and teaching mixed to achieve balance while vigorously developing interdisciplinary innovation and entrepreneurship education, and entrepreneurship education is a realization form of the result of application-oriented education in the later period.

\section{RESEARCH ON COLLABORATIVE-INNOVATION AND SYSTEM- INNOVATION SYSTEM IN APPLIED UNIVERSITY}

The establishment of a reasonable and scientific system is the necessary measures to ensure the reformation, also is the strong support to promote the transformation and development of the school. Under the planning of national "thirteen five" plan and the school "innovation strong school project", construction of innovative institutional mechanisms of the system, guidance and improve the construction and training of teachers, collaborative innovation, school-enterprise cooperation, personnel reform, student training incentives, laboratory construction, etc., in order to guide the transformation and upgrading of the application-oriented colleges to improve the overall level of development of the school.

\section{A. To establish a rational structure of teachers and optimize the backbone teachers}

In the beginning, independent colleges have got a rapid development by using parent school teachers. As the independent college from construction to the present development has formed its own full-time teacher's team. The team is mainly composed of young teachers, therefore the degree distribution is not reasonable, and lack of high-end talent, but it should be noted that the current university has followed the same pattern of development and the training of talent, it's also related to the teaching staff, especially the student who has been criticized, more separate themselves from the social practical demand. The main problem is that colleges attach importance to theoretical teaching, the emphasis on practical teaching for vocational schools, lacks of vocational upgrading, and then the application-oriented undergraduate colleges play a good cohesive action, which can strengthen the educational development of technology theory and practice. Applied undergraduate colleges and universities should establish the reasonable structure of teachers, not only to vigorously introduce the high-end talent with a doctorate degree but also to cultivate a double division type of young teachers who have a reasonable distribution in educational background, not blindly only academic credentials theory. We should diversify the development of teaching staff, many young teachers lack the practical training of enterprises, in this case, is inevitable to theory-based teaching. At the same time, the situation of paid more attention on research and less on teaching is also the defect of the examination system, so it is necessary to solve the teacher's employment management and optimization of the evaluation. Under the premise of ensuring the reasonable distribution of teachers' academic credentials, through the enterprise training, project cooperation and teaching practice and training, vigorously improve the teachers' practical ability. So that double lifting the full-time teachers' theoretical and practical level. Select of excellent teachers from the full-time teachers to form a leading role, build an application oriented teacher team that with reasonable structure, high level of business, practice teaching ability, and academic potential.

\section{B. Professional certification reform and personnel training program revision}

In June 2016, China became the official member of the "Washington Accord", engineering education certification system has been internationally recognized, and engineering education development has step onto a new level, for further promote the role of engineering education certification and quality improvement[6]. Independent colleges in the transition process of application-oriented colleges, cultivate the application of innovative technology and skilled talents for the regional economic service-oriented, deepen the reform of practical education. In this context, the engineering education certification as an opportunity to explore the local undergraduate colleges of the new education system, in accordance with the standards and requirements of engineering education certification to develop new teaching plans and talent training programs, combined with the actual situation of our school, turned to the education reform of engineering education certification, and further strengthen the connotation and quality construction in the transformation process. The talent training program of application-oriented universities directly reflects the reform of its talent training mode. That is, how to match with professional certification, and the realization of the local industry chain, professional standards, technical demand is relatively connected. Construct new curriculum practice teaching system based on industry and occupation standard, in the specialized courses, the compulsory course, the experimental class and the second class above seamless connection, promote project oriented, case-based, research and development, using a variety of modern information technology and virtual simulation technology, under the premise of solving the equipment shortage or insufficient resources, extensively use of various means to cultivate innovative entrepreneurial talent. The course of study is based on the project, which enables students enter the laboratory earlier, practice earlier, to master the relevant methods and skills of research and development, change the way of examination in the form of big operation, project, and paper, take the standards and requirements of registered engineers to strengthen the training of students' practical ability. The major of Electronic Information Science and Technology and Electrical Engineering and Automation has started the implementation of professional certification in our college, revised the talent training program according to the standard, established the roadmap of the curriculum, and set up innovative training courses in different grades as required courses. 


\section{To strengthen the collaborative innovation cooperation of school, school-government and school-enterprise, establish experimental teaching demonstration center and practice teaching base on campus}

Application-oriented colleges and universities should be based on local and provide excellent talents for local, make its own contribution to local economic services, the depth the cooperation with local government, and cooperation innovation of local enterprises, to establish collaborative linkage mechanism between schools in different ways. Establish various forms of cooperation with universities in the region, mutual visits, learn from the experience of local colleges, and cooperate with each other in the way of students' competition. In the Dongguan campus of our college based on the form of science and art festival, host certain types of competition; also send the team to participate in other school-sponsored competitions, in this way to interact with each other, learning from each other. Our college also has academic exchanges and cooperation with foreign universities, inviting well-known professors from foreign universities to conduct academic guidance and lectures, forming a certain scale of cooperation in running schools. In the school-enterprise cooperation, and continuously with the various types of enterprises to establish a broad and in-depth cooperation, build curriculum, the introduction of enterprise engineers to participate in the development of teaching plans, also hired a large number of part-time engineers, gradually from the secondary college to establish the relevant management system to promote schoolenterprise cooperation in education, achieve the integration of professional education, engineering education and innovation and entrepreneurship education. In the internship stage, through various ways to strengthen the internship and employment guidance, give full play to the local enterprises and the government's collaborative role, to encourage students to choose the nearest internship and work, and truly provide high quality talents for the local economy, in order to development through the cultivation of quality talent, to serve the local economy oriented, As a real place on the application of technical skills colleges. Establish experimental teaching demonstration center in the school, vigorously promote the establishment of school practice teaching base, at the same time, we should also strengthen the construction of practice teaching base in schools, introduce enterprises into the school to cultivate talents, and encourage students to start their own businesses, the establishment of entrepreneurial practice base, and provide relevant support policies, and combined with the local government's college student entrepreneurship policy, guide students from on-campus to out-campus entrepreneurship program, the implementation of collaborative innovation management from school to local government.

\section{CONCLUSION}

In the process of promoting the transformation of the local undergraduate colleges in the training of applied talents, we should avoid short-term blind expansion and to meet the market demand only focus on the short-term training of technical personnel development model, thus ignores the future market and technology development needs and the demand for innovative capacity. The reason of this situation is because the short-term cultivation of utilitarianism, which has blindly denied the theory of teaching, will lead to the decline of the quality of undergraduate education. Although there is a strong demand for docking with the higher vocational colleges, it cannot completely copy the model of vocational education, deny the advantages of traditional teaching methods. To strengthen the application of practical training doesn't mean indiscriminately ignore the theoretical teaching, but should allow students to practice earlier. In order to avoid too much theoretical study, which leads to the decrease of students' learning interest and learning fatigue, making the goal and direction not clear. So it is necessary to establish the system of innovative education mechanism, and the engineering education practice can throughout college. Interspersed in the theory of teaching, in order to understand and analyze the theory of engineering practice, and to cultivate interdisciplinary talents with innovative and entrepreneurial and applied technical skills. Through the top-level design, make relevant systems to ensure the rapid development of applicationoriented colleges, through various ways to promote the cultivation of double-qualified teachers, vigorously develop the subject competition, and radiate to the whole students. Take encouraging measures to guide students to carry out research and develop projects, establish various kinds of experimental teaching demonstration center, strengthen cooperation between schools and enterprises, and strive for win-win cooperation and establish a community of interests, so that enterprises truly active participation. To create characteristics and brand major, systematic cultivation of innovation ability, curriculum reform from the bottom to the top, and revised talent training program, and ultimately in accordance with the developing process and orderliness, take different development stages and with the system of innovation mechanism, to construct the training mode of innovative and entrepreneurial and applied technical skills talent.

\section{REFERENCES}

[1] The Central People's Government of the People's Republic of China, National Medium-Long-Term Educational Reform and Development Plan (2010-2020), July 2010.

[2] Ministry of Education of the People's Republic of China, Opinions of the Ministry of Education on improving the quality of higher education (higher [2012] No.4), March 2012.

[3] China Education News Network, 178 colleges jointly issued the “Zhumadian consensus”, April 2014.

[4] The State Council Information Office of the People’s Republic of China, State Council on accelerating the development of modern occupation education decision, June 2014

[5] Ministry of Education of the People's Republic of China, Directive opinion of the transformation of local colleges into applied technical colleges ([2015] No.7), October 2015.

[6] China Engineering Education Accreditation Association, Notice on carrying out the application for Engineering Education Accreditation in 2017, September 2016. 